\title{
The Convergence of Onomatope Animal Sounds between Indonesian And English
}

\author{
Ruli Hapsari \\ Universitas Islam Indonesia Yogyakarta \\ e-mail: ruli.hapsari@uii.ac.id
}

\begin{abstract}
This qualitative study is aimed at discovering the similarities of onomatope (not onomatopoeia) animal sounds between two unrelated languages, Indonesian and English. The investigation operates on phonological system with some goals to achieve; to describe how sounds of onomatope animal correspond, to explain why the two languages share similarities in their onomatope animal sounds.

The data in this research are from Indonesian and English comics which are backed up by interviews with twenty-six informants consisting of eleven adults and fifteen children. The interviews are aimed at reinforcing the collected data and also disqualifying several lingual units which under suspicion of loan sound imitations.

The research findings reveal that out of 22 (twenty-two) onomatope animal sounds gathered as the research data, there are only 15 (fifteen) sharing the same phoneme distribution after conducting sound correspondence. The phoneme distribution occurs mostly on onset position, the second is on coda position, and the least is on nucleus position. There are three factors which evoke the similarities or that can be called convergence. First, because of similarities in phoneme inventories. Second, because of similarities in phonotactic rules. Third, because of same sound symbolism which apply to both Indonesian and English.
\end{abstract}

Keywords: onomatope, sound correspondence, convergence, similarities of sound symbolism, language-specific.

\section{Background}

A language consists of signs. They contain two inseparable aspects, namely concepts and sound-images. Ferdinand de Saussure (1857-1913), the founder of modern linguistics, has named sound-images signifier and concepts signified. The important thing that needs to be underlined is the relationship between the signified and the signifier is called arbitrary and conventional. However, is it always true if the relationship between the two in a language is always arbitrary and not touched by intrinsic factors?

Since the time of Plato, philosophers and linguists have thought of nonarbitrary relationship between the symbol of sound and its meaning. This has led to the theory of sound symbolism, which covers many fields of subordinate study of nonarbitrary relationship between sounds and meanings. One of the coverage areas of sound symbolism is onomatope, sound imitator words. Semantics experts make sure that every language has onomatopoeic words, but few in number rather than arbitrary lingual forms. This little portion seems to make it a marginal group in langue, so not 
many language researchers pay attention specifically on this scientific object. Accordingly, in studying a language, there are several reasons to put forward related to the interest in onomatope research. Firstly, onomatope research is intended to counterbalance contemporary linguistic research that mostly concentrate on lingual forms which are arbitrary. Secondly, onomatope has 'the right to live' which is the same as those arbitrary - needs to be discussed, studied and mastered by the language users. Thirdly, onomatope study as one of the many onomatope studies that position themselves in opposition to the status quo - the belief that upholds the arguments of arbitrariness relationship between linguistic signs, in order to reorganize the knowledge of the role of sound and meaning, especially in onomatope.

The onomatope to be investigated in this research is that of Indonesian and English, especially onomatope animal sounds. There are a few rationales of choosing the two languages. English and Indonesian are two languages that originate from different language families. Indonesian is a language located in an area of Austronesia language family, while English is a member of Germanic languages included in a big family of Indo-European language. The two languages allegedly share animal onomatope vocabularies which are convergent due to language universality, especially phonological universal. The fundamental point as a belief in this research is that behind an idiosyncrasy owned in different languages, there must be uniformity which in turn end up in the same patterns (Greenberg, 1961). Thus, this research attempts to discuss, (1) how are the sound correspondences between English and Indonesian onomatope animal sounds? And (2) why similarities are found between English and Indonesian onomatope animal sounds?

\section{Theoretical Framework}

\subsection{Onomatope and Onomatopoeia}

Onomatope and onomatopoeia are often used interchangeably. However, there is a subtle difference between the two terms. The term onomatope (Onomatopoeia) originates from ancient Greek, that is composed from the Greek words onoma, "name," and poiein, which means "to act, action" (Peters, 1967, page 162). Clark (2000) defined it as the "formation of a word that sounds like its referent, as buzz, crack, cuckoo". This is in line with onomatope definition by Kridalaksana (2008, p 167), "Onomatope adalah penamaan benda atau perbuatan dengan peniruan bunyi yang diasosiasikan dengan benda atau perbuatan itu; misalnya, berkokok, suara dengung, deru, aum, cicit, dsb." Words in bold show similarities in the two definitions, i.e. the similarity of the concept on the formation of a name or word by Peters and naming objects or actions by Kridalaksana. This concept refers to onomatope of words/names formed after sound imitating phase, so it is not direct imitation sound.

Natural sound Imitative sound Word formation Language

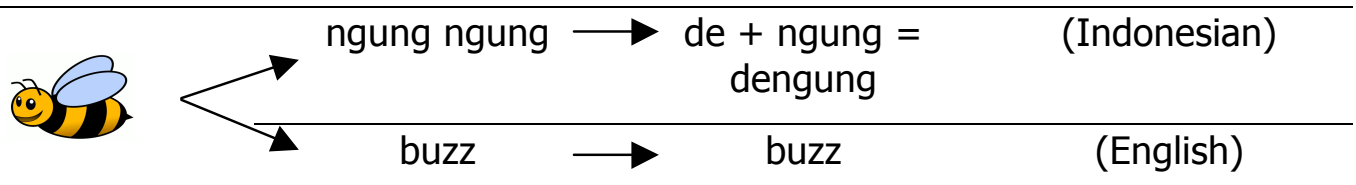


The scheme above explains about onomatope concept contained in the two definitions, that what are called by onomatopoeic words are in the column 'word formation'. It implies that onomatope according to Peters and Kridalaksana, is formed words, not the sounds imitating directly the referents. The word dengung in Indonesia is the sound name which is formed by prefixation process of de-, just as denting, dentum, deru. Meanwhile, the word buzz in English is formed from imitative sound buzz, so that it can be said that the word buzz has undertaken a morphological process of zero derivation. In English there are many such words - imitative sounds with zero derivation which in turn derive verbs and nouns, such as: crack, clap, slap, smash, sniff, etc.

Beside the two definitions, there are other definitions which are dichotomic. In grammar.about.com, it is found a distinction between onomatope and onomatopoeia. Onomatope is the words imitating the sound of referents, while onomatopoeia is word formation or the use of words imitating sounds, related to objects or actions referred. This definition is in line with that in Kamus Besar Ilmu Pengetahuan which provides a dichotomy on onomatope definition. Onomatope is the words formed based on natural sounds, for example the word "kokok" is an imitative sound of chickens, "cicit" is an imitative sound of mice, while onomatopea is word formation by imitating natural sounds, for example: dengung lebah, meong kucing, aum harimau, deru angin (Dagun, 2000, p 744). If these are related with previous definition, by Peters and Kridalaksana, so they are equivalent with onomatopoeia (grammar.about.com) and onomatopea (Dagun, 2007, p 744).

Based on the duality of onomatope definition, from grammar.about.com and Kamus Besar Ilmu Pengetahuan, this research focuses on onomatope, that is the words imitating directly the sounds of referents, not onomatopea/onomatopoeia. That is why the word onomatope is used throughout the paper.

\subsection{Phonology System of English and Indonesian}

Each language has a repertoire of sounds selected from all the possible sounds that can be produced by humans, and it is different from other languages. Indonesian has a total of six vowel phonemes - /i/, /e/, /a/, /u/, /o/, /ə/, twenty-two consonant phonemes - /p/, /b/, /t/, /d/, /k/, /g/, /t /, /d3/, /f/, /s/, /z/, / /, /x/, /h/, /l/, /r/, /m/, /n/, /ñ/, /n/, /w/, /y/ and three diphthongs - /ai/, /au/, /oi/ (Alwi, Dardjowidjojo, Lapoliwa, Moeiliono, 2014, p 57-67). In English, especially in consonant system of English, the total phonemes are relatively the same to all accents of English. The difference is just about vowel system. Giegerich in his book English Phonology: An Introduction (1992, p 43-87) provides a comprehensive review of the system of phonemes phonology from three accents of English, namely English spoken in Britain which is called Received Pronunciation (RP), spoken in Scotland called the Scottish Standard English (SSE) and spoken in the United States called General American (GA). This section will not discuss the three accents, but one of the three, that is RP. RP has twelve vowel phonemes - /i/, /u/, /I/, /u/, / /, /e/, /ə/, /3/, /æ/, / /, /a/, /D/, twenty-four consonant phonemes - /p/, /b/, /t/, /d/, /k/, /g/, /ts/, /d3/, /f/, /v/, / /, , $/$ /, /s/, /z/, / /, /3/, /h/, /l/, /r/, /m/, /n/, / //, /w/, /j/ and eight diphthongs - /eI/,

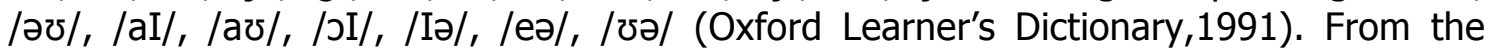


description, English and Indonesian are two languages with phoneme inventories which are almost similar.

Despite the similar phoneme inventories, the construction of these phonemes to form syllables and words is subject to the rules of each language, such as clusters and sequences of consonant vowel that are allowed, how clusters and sequences are placed/positioned in syllables and words. A phonology aspect dealing with this problem is called phonotactics, which is the basis in discussions for answering why there are similarities and differences in a series of onomatopoeic sounds in English and Indonesian. Syllable belongs to the realm of phonotactics study, a unit of the sound characterized by a unit of the most sonorous sound, which can be accompanied or not by other sound in front, behind or at once in front and behind (Chaer, 1994, p 101). The peak of sonority signifies syllable. The peak, or the point of greatest volume of sounds is formed by vowels. Regarding syllable structure, a distinction is drawn between nucleus (the peak), onset (the beginning of the syllable) and coda (end of the syllable) (Bussman, 2006, p 1155).

\section{Data Collection Method}

The onomatope data gathered in this research are the animal sounds frequently heard and produced in daily life. For example, onomatope of animals with audible sounds that are often found and show up in fairy tales or picture stories. The method of data collection is observation method by recording technique and interview method by recording technique.

The data of English onomatope animal sounds were gathered from written source in the form of comics, and from oral source which is interview with two native speakers of English. The English comics are The Adventures of Tintin edition 1 - 30, Asterix 17 edition, Donald Duck edition 3 - 37, Franquis Black Ideas, and Garfield. Similarly, the data of Indonesian onomatope animal sounds were gathered from comics, they are Kungfu Komang (20 comic books), Kungfu Boy edition 20, and Fight Ippo edition 1. Those having the theme of violence were chosen because they contain more sound imitations than those of teenlit comics (teen literature). Furthermore, the Indonesian data were strengthened by interview results. The interviewees are 26 informants who are composed of eleven adults in the age range of 20 to 30 with diverse culturally background and fifteen children of third and fourth grade from a private elementary school in the city. The interview results are meant to strengthen the data from the written source and to abort some lingual units which are allegedly borrowed from foreign languages. This measure was taken for gaining the valid data. As extra source, other written sources were also used, such as articles, and prior research findings related to the topic.

\section{Research Findings}

This section discusses the uniformity, namely the similarities of onomatope animal sound patterns between Indonesian and English. The similar patterns are to be achieved by referring to phonological system of Indonesian and English that has been described in section $\mathbf{2 . 2}$.

The data population are the animal sounds often heard in daily life or from animals whose sounds are audible, often found and show up in fairy tales or story books. The number of animal sounds gathered are 22 (twenty-two), but there are 
only fifteen which enable sound correspondence. The following are the 15 (fifteen) animal imitating sounds.

\begin{tabular}{cc}
\hline Indonesian & English \\
\hline KUKURUYUK & COCK-A-DOODLE-DOO \\
{$[$ kukuruyuk $]$} & {$\left[\mathrm{k}^{\mathrm{h}}\right.$ Dkə dudl du $]$}
\end{tabular}

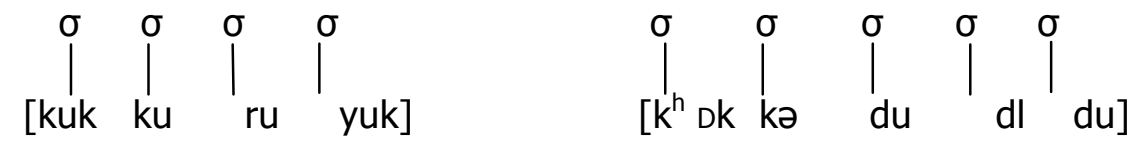

The onomatope of chicken from the two languages is polysyllabic, Indonesian has four syllables and English has five. From the syllables, the first two syllables seem to show sound similarity, so that correspondence is conducted as follows. The first syllable $k u-\sim k D k-$, and second syllable $-k u-\sim-k ə-$.

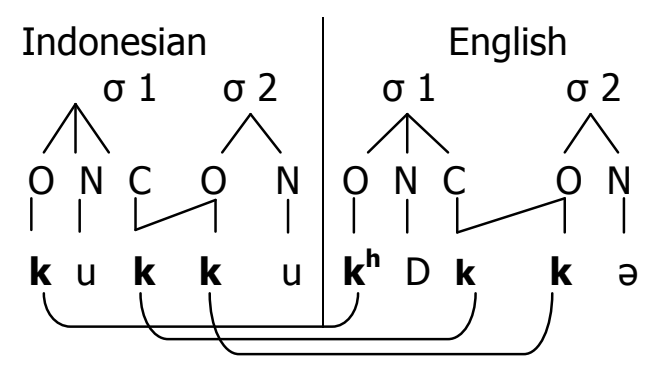

The finding of its sound convergence is chicken onomatope of Indonesian and English is dominated by stop velar sound $[\mathrm{k}]^{1}$ in onset and coda position of the first syllable and in onset position of the second syllable.

\begin{tabular}{lll}
\hline Indonesian & English \\
\hline MOO [moo] & MOO [mu $]$ & Con
\end{tabular}

The onomatope of cow in two languages is monosyllabic. The sound segmentation shows a convergent sound which occupies onset position, that is nasal bilabial $[\mathrm{m}]$.

\footnotetext{
${ }^{1}$ The feature of voiceless stop velar $[\mathrm{k}]$ in English is aspirated which is an allophone of phoneme $/ \mathrm{k} /$ that differs from Indonesian. Nevertheless, allophone discussion is excluded here, because correspondence is aimed at seeking the same typical phonemes which occupy the same position within syllable internal structure.
} 


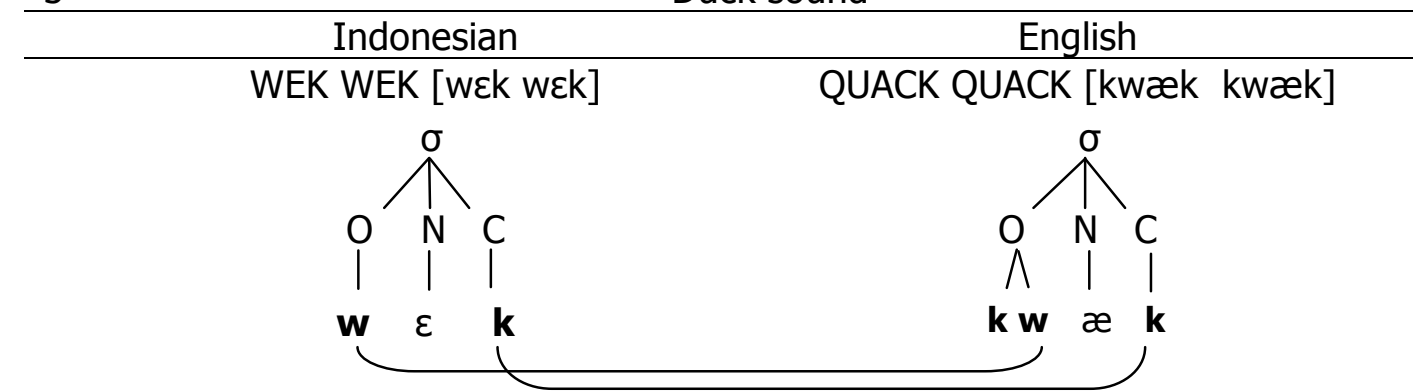

For duck imitating sound in Indonesian, the interview result with 26 informants shows that 13 informants ( 9 adults and 4 young informants) imitated duck sound by kwek kwek and 11 other informants ( 1 adult and 10 young informants) by wek wek. The segmenting then used wek wek because kwek kwek is suspected of being borrowed from English.

The duck onomatope in the two languages is a type of full reduplication onomatope, each of its morphemes is monosyllabic. From the segmentation, it is known that there is a sound similarity in coda and onset position. In onset position, there is a semi-vowel $[\mathrm{w}]$, and velar stop [k] in coda position.

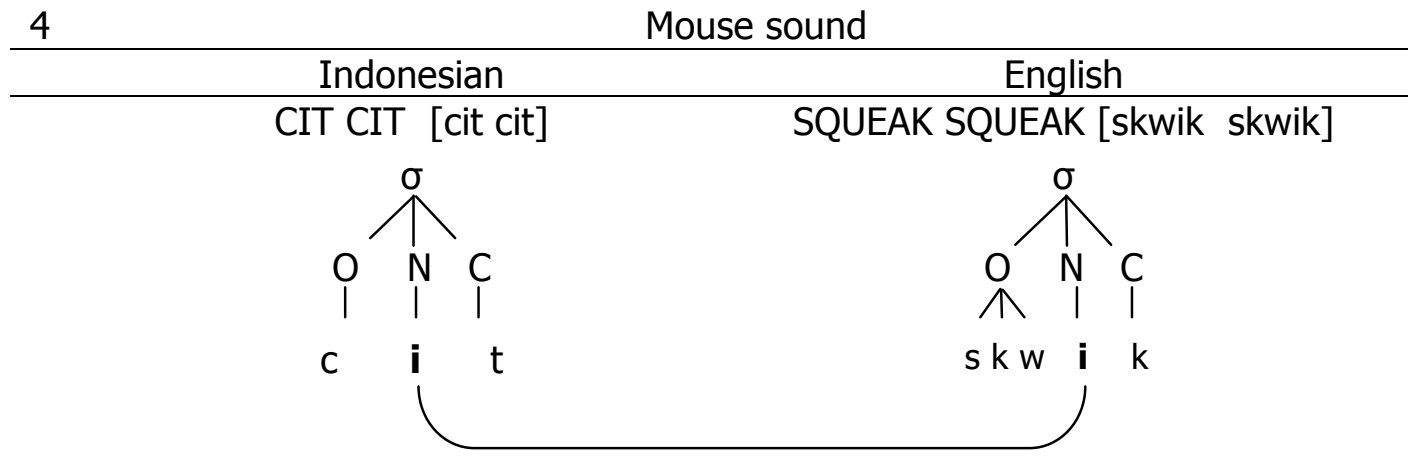

The mouse onomatope in the two languages is a type of full reduplication onomatope, each of its morphemes is monosyllabic. From the segmentation, obtained one same sound, that is high front unrounded vowel [i].

\begin{tabular}{ccc}
\multicolumn{3}{c}{ Crow sound } \\
\hline Indonesian & English \\
\hline KOAK KOAK [koak koak] & KRA KRA [kra kra] \\
\cline { 2 - 2 } &
\end{tabular}




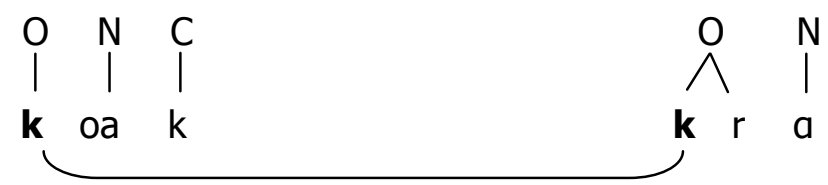

For crow imitating sound in Indonesian, the interview result with 26 informants shows that 2 adult informants imitated crow sound by kak kak, and 1 informant by $a k a k$, and 2 other informants by koak koak. And the rest did not know. Then the segmenting used koak koak.

The crow onomatope in the two languages is a type of reduplication onomatope, each of its morphemes is monosyllabic. The convergent sound found is velar stop [k] in onset position.

6

Dog sound

\begin{tabular}{cc}
\hline Indonesian & English \\
\hline GUK GUK [guk guk] & WOOF WOOF [wठf wठf] $]$
\end{tabular}

The dog onomatope in the two languages is a type of full reduplication onomatope, each of its morphemes is monosyllabic. In English, there are a number of variations for dog imitating sound, such as woof woof (RP), bow wow (GA), arf arf, rowf, harf. Nevertheless, there is only one sound used here to be contrasted with Ind. From the segmentation, the convergent sound found is in nucleus position, that is rounded vowel $[u]$.

Frog sound (big sized)

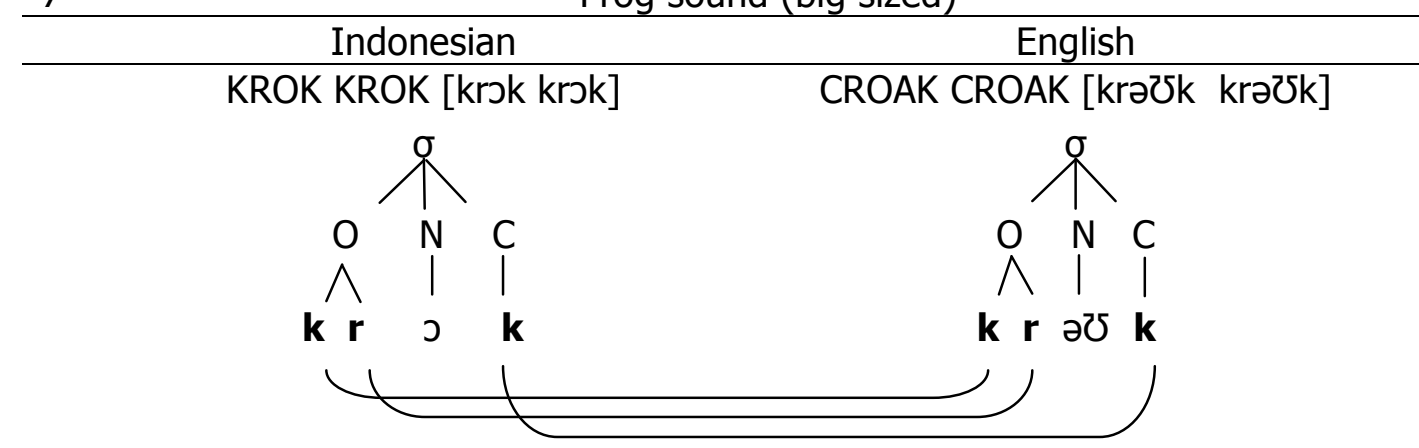

The onomatope of bigger frogs in the two languages is a type of full reduplication onomatope, each of its morphemes is monosyllabic. From the segmentation, three same sounds are found, they are velar stop [k] and tril [r] in onset position, and velar stop [k] in coda position.

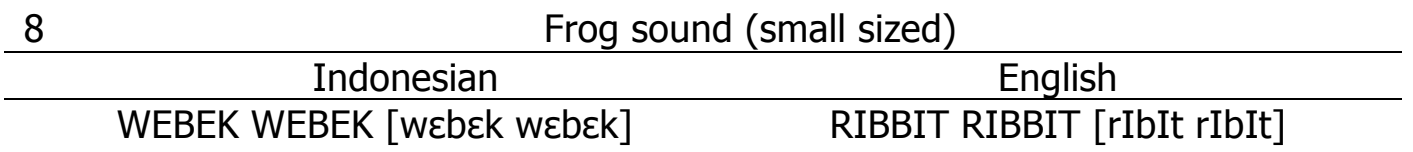




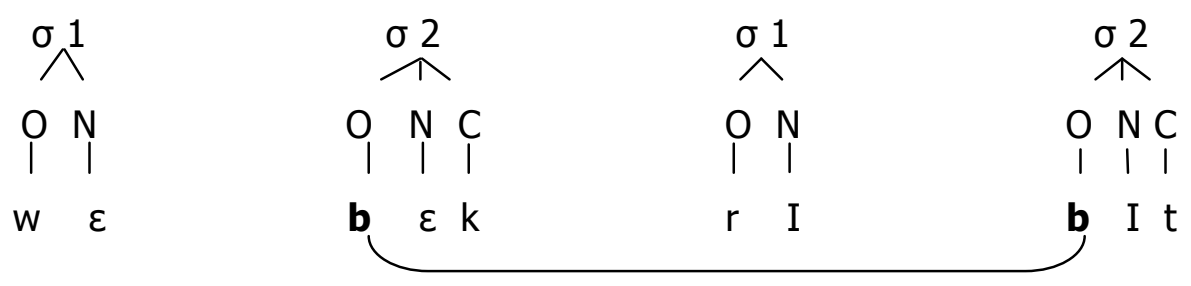

The onomatope of little frogs in the two languages is a type of full reduplication, each of its morphemes is bisyllabic. In Ind, there are two variations of this onomatope obtained from interview result, webek webek and kribik kribik. Nevertheless, one sound only is then used to be contrasted with its equivalent in English. The result is, in penultima syllable of Indonesian [wE] and English [rI], there is no sound similarity, while in ultima syllable of Indonesian [bek] and English [bIt], sound similarity is found. The only sound which is the same in the syllable takes place in onset position, that is bilabial stop [b].

9

Goat sound

\begin{tabular}{|c|c|}
\hline Indonesian & English \\
\hline MBEEEK [mbsk] & $\begin{array}{l}\text { BLEAT [blit] } \\
\text { BAAH [ba] }\end{array}$ \\
\hline \begin{tabular}{ccc}
$\bigwedge_{m}$ & $\left.\right|^{N}$ & \multicolumn{1}{c}{$\mid$} \\
$\mathbf{b}$ & $\varepsilon$ & $k$
\end{tabular} & 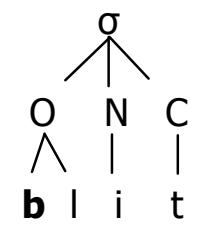 \\
\hline
\end{tabular}

The goat onomatope in the two languages is a type of monosyllabic onomatope. In English, bleat is a sound imitation that refers to either goats or sheep, while baah refers to sheep (www.writtensound.com). The convergent sound found is voiced bilabial stop [b] in onset position.

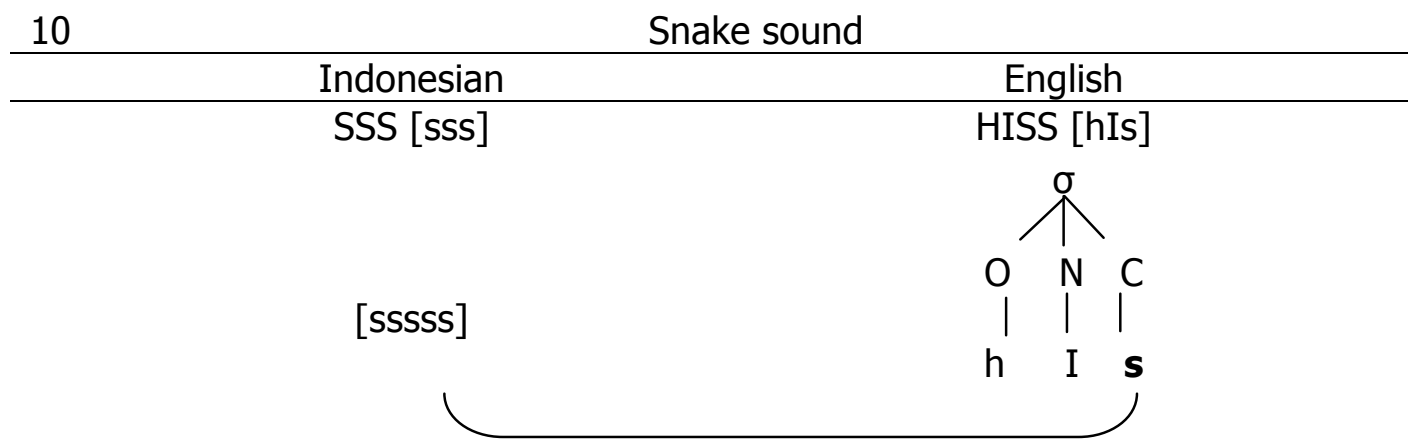

The snake onomatope in English is a type of monosyllabic onomatope, that it can be segmented accordance with its syllable internal. Meanwhile, in Indonesian the snake onomatope is only a series of fricative sound [s], no element of sonority which is the requirement of a syllable. Thus, [ssssss] cannot be segmented. However, sound correspondence can be still conducted which in turn yields the same sound distribution, that is voiceless fricative $[\mathrm{s}]$.

Little bird sound 


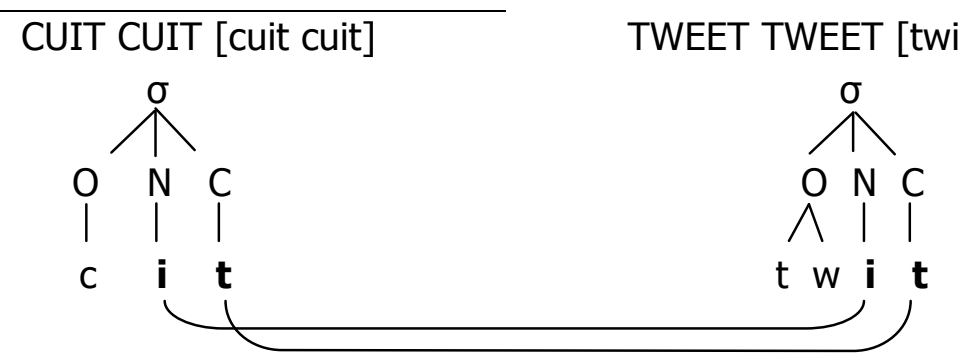

There are two variations for imitative bird sound in Indonesian obtained from interview result, cuit cuit and cit cit. Apart from the variation, the onomatope is a type of full reduplication onomatope, each of its morphemes is monosyllabic. cit cit is then used to be corresponded with its English equivalent. From the segmentation, two convergent sounds are found, they are high front unrounded vowel [i] in nucleus position and dental stop [t] in coda position.

12 Donkey sound

HII HAA [hi ha]

HEEHAW [hi ho]

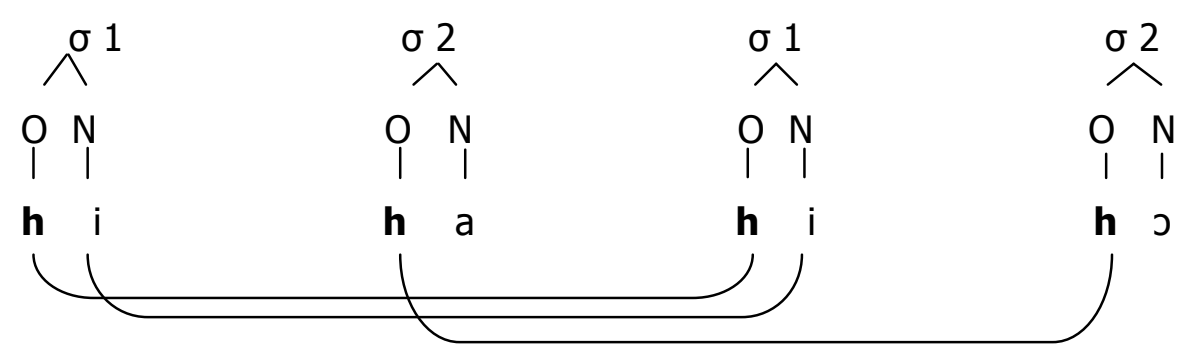

The donkey onomatope in the two languages is a type of bisyllabic onomatope. From the segmentation, the convergent sound is glottal fricative [h] which occupies onset position in the two syllables and high front vowel [i] in nucleus position of penultima syllable.

13

Gecko sound

Indonesian $\quad$ English

The gecko onomatope in the two languages is a type of disyllabic onomatope. One convergent sound is known after segmenting, that is velar stop [k] in onset of ultima syllable and in coda of penultima syllable.

\begin{tabular}{ccc}
14 & Goose sound \\
\hline Indonesian & English \\
\hline KWONG KWONG [kwon kwon] & HONK HONK [honk honk]
\end{tabular}




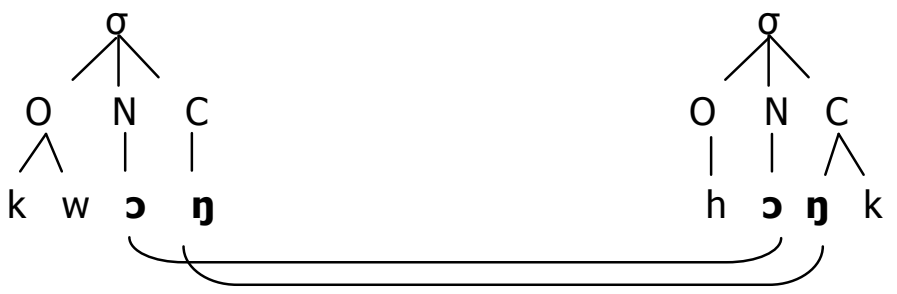

The goose onomatope in the two languages is a type of full reduplication onomatope, each of its morphemes is monosyllabic. The sound convergence discovered is low back rounded vowel [0] in nucleus position and velar nasal [D] in coda position.

Cat sound

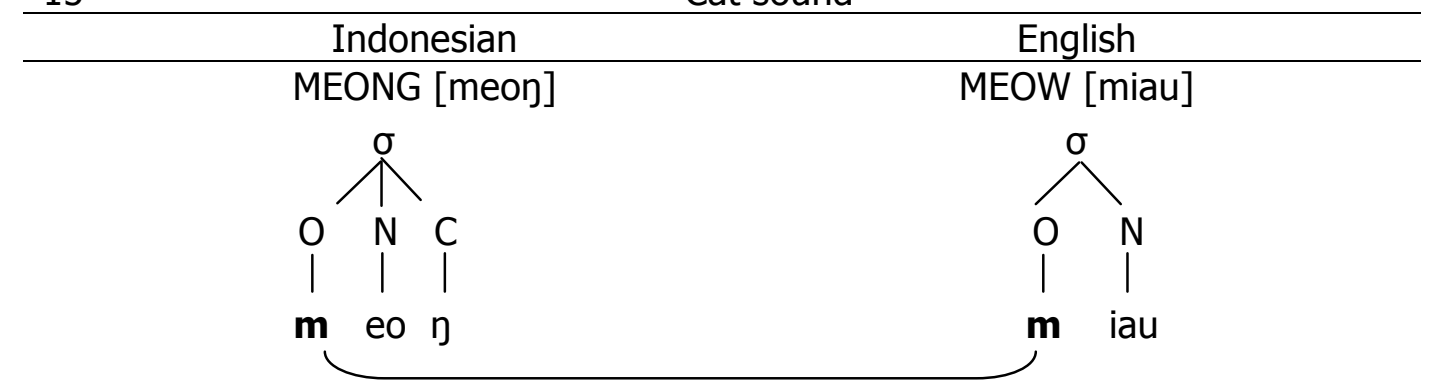

The cat onomatope in the two languages is a type of monosyllabic onomatope. From the segmentation, one convergent sound is found, that is bilabial nasal $[\mathrm{m}]$ in onset position.

\section{Discussion}

\subsection{Similarity of Phoneme Inventory}

In section 2.2. it has been explained similarity of phonology system between Indonesian and English. After segmenting and corresponding sounds in section 4, this section is to recapitulate convergence of typical phonemes as a result of the similarity of phonological system.

Table 5.1. Typical phonemes for onomatope animal sounds

\begin{tabular}{|l|l|c|c|}
\hline No & Animal Onomatope & Typical phoneme & Position \\
\hline 1 & Chicken & $/ \mathrm{k} /$ & onset, coda \\
\hline 2 & Cow & $/ \mathrm{m} /$ & onset \\
\hline 3 & Duck & $/ \mathrm{w} /+/ \mathrm{k} /$ & onset, coda \\
\hline 4 & Mouse & $/ \mathrm{i} /$ & nucleus \\
\hline 5 & Crow & $/ \mathrm{u} /$ & onset \\
\hline 6 & Dog & $/ \mathrm{k} / \mathrm{r} / \mathrm{r} / \mathrm{k} /$ & nucleus \\
\hline 7 & Frog (big sized) & $/ \mathrm{b} /$ & onset, coda \\
\hline 8 & Frog (small sized) & $/ \mathrm{b} /$ & onset \\
\hline 9 & Goat & $/ \mathrm{s} /$ & onset \\
\hline 10 & Snake & $/ \mathrm{i} /+/ \mathrm{t} /$ & coda \\
\hline 11 & Little bird & $/ \mathrm{h} /$ & nucleus, coda \\
\hline 12 & Donkey & $/ \mathrm{k} /$ & onset \\
\hline 13 & Gecko & & coda, onset \\
\hline
\end{tabular}




\begin{tabular}{|c|l|c|c|}
\hline 14 & Goose & $/ \mathrm{o} /+/ \mathrm{g} /$ & nucleus, coda \\
\hline 15 & Cat & $/ \mathrm{m} /$ & onset \\
\hline
\end{tabular}

Table 5.1 shows that the phoneme distribution occurs mostly on onset position, amounting to 10 animal onomatope sounds (chicken, cow, duck, crow, largesized frog, little-sized frog, goad, donkey, gecko, cat). The second mostly occurred distribution is on coda position, by 7 sounds (chicken, duck, large-sized frog, snake, little bird, gecko, goose). The least occurred distribution is nucleus position, by 4 sounds (mouse, dog, little bird, goose).

\subsection{Similarity of Phonotactics Rules}

We can see that two unrelated languages with nearly similar phoneme invetory, enable to have rules which are more or less similar regarding phoneme distribution in syllable and word formation. The following table contains evidence of similarity of phonotactic rules that yields convergence of onomatope sound. The evidence can only be found in two segments which occupy onset position.

Table 5.2. Convergence of consonant cluster

\begin{tabular}{|c|c|c|c|}
\hline Consonan & Onomatope & Indonesian & English \\
\hline$/ \mathrm{kr} /$ & $\begin{array}{lll}\text { Frog } & \text { sound } & \text { (big } \\
\text { sized) }\end{array}$ & [krJk krok] & [krəびk krəひ"k] \\
\hline
\end{tabular}

\subsection{Similarity of Sound Symbolism}

Research on sound symbolism firstly started with the investigation of sound symbols whose meanings are associated with magnitude symbolism, especially vowel sounds. Edward Sapir initiated this research in $1929^{2}$ which in turn gave rise to further studies by other researchers (Nuckolls,1999, page 230).

Magnitude symbolism consists of two concepts, diminutive - the concept associated with small notion, and augmentative concept - the concept associated with big notion. This section is to find out the same patterns of sound symbols, which apply either in Indonesian or English.

\subsubsection{High Vowel Ö Back Vowel}

The relationship between small size and vowel /i/, and between large size and vowel /a/ is called magnitude symbolism. Thus, the higher the vowel sounds or getting to the front, it is increasingly understood by all that is small size. Conversely, the lower the vowel sounds or getting to the back, then the meaning is enlargement. This pattern can be outlined as follows.

Table 5.3.1 Scheme of magnitude symbolism for vowel sounds

\footnotetext{
${ }^{2}$ Sapir experimented with two artificial words $\mathrm{mil}$ and $\mathrm{mal}$, then the arbitrary referent 'table' was provided for the words. 500 informants were asked which one is the word, mil or mal that refers to small and large table. $83 \%$ of children and $93 \%$ of adults consistently made an answer mil for small table.
} 
(adapted from Silverstein in Hinton, 1994)

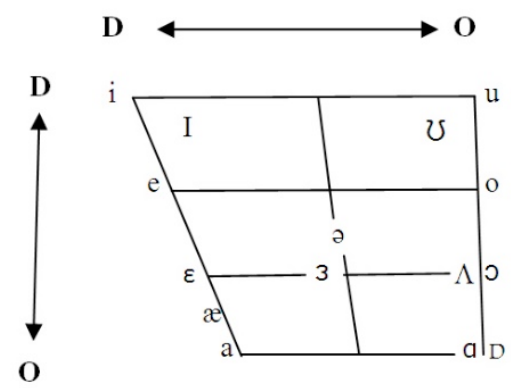

In addition to diminutive meaning for high vowel sound and augmentative meaning for low vowel sound, there are other meanings attached to the vowel sounds, such as light and dark, fast and slow, near and far. The motivation that underlies magnitude sound symbolism is the combination of articulatory, acoustic and biology factors (Nuckolls,1999, page 230).

\section{Front Vowel}

Either in Indonesian or English, phoneme of front vowel is believed to present small information or things with small shape. The interpretation is based on articulatory factor, for example front high sound [i] is articulated by elevating the tongue until it almost touches the palate, causing the oral cavity becomes narrow and small. In the meantime, the bilabial seems not to extend much. So, upper and lower lip make up a narrow cavity. This narrowness suggests small meaning. Beside small meaning attached to high vowel, other meanings are also attached, such as light, shiny and sharp. The following are the evidences found in animal onomatope of Indonesian and English.

Table 5.3.1.1 Evidence of high vowel which means small

\begin{tabular}{|l|c|c|}
\hline \multicolumn{3}{|c|}{ Diminutive meaning } \\
\hline \multicolumn{1}{|c|}{ Onomatope } & Indonesian & English \\
\hline Mouse & {$[$ cit cit] } & {$[$ skwik skwik] } \\
\hline Little bird & {$[$ cit cit] } & [twit twit] \\
\hline Small-sized frog & {$[$ webek webck] } & {$[$ rIbIt rIbIt] } \\
\hline
\end{tabular}

The asterisk sign for Indonesia [cuit cuit] is the exception because it is a diphthong /ui/. Since the movement of this diphthong begins from back vowel to front, hence it is called diminutivization.

Table 5.3.1.2 Scheme of diminutivization movement [cuit cuit] 


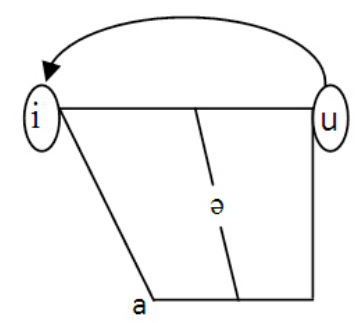

Thus, bird imitating sound in Indonesia [cuit cuit] remains to refer to birds with small body, or smaller than crows.

\section{Back Vowel}

When front vowel informs small things, otherwise back vowel phoneme is believed to inform large things. This interpretation is based on articulatory factor, for example low sound [a] is articulated without the touch between the tongue and the hard palate, so that the oral cavity becomes wide open. This form is utilized to suggest augmentative meaning. The following are the evidences found in onomatope of Indonesian and English.

Table 5.3.1.3 Evidence of back vowel which means large

\begin{tabular}{|c|c|c|}
\hline Onomatope & Indonesian & English \\
\hline Chicken & [kukuruyuk] & [k $\mathrm{k}^{\mathrm{h}}$ D dudl du] \\
\hline Bigger-sized frog & [krok krok] & 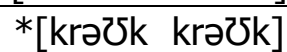 \\
\hline Goose & [kwon kwon] & [honk honk] \\
\hline Crow & $\begin{array}{c}*[\text { keak keak }] \\
*[\text { kaok kaok }] \\
{[\text { kak kak }]}\end{array}$ & [kra kra] \\
\hline Cow & {$[\mathrm{moo}]$} & {$[\mathrm{mu}]$} \\
\hline Dog & [guk guk] & 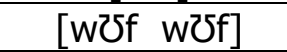 \\
\hline Cat & $*[$ meon $]$ & $*[\mathrm{miau}]$ \\
\hline
\end{tabular}

A series of sounds with asterisk sign * are the exception because they are diphthong and thriphthong. The diphthong movement that starts from front to back vowel and from high to low is called augmentativization.

Table 5.3.1.4 Scheme of augmentativization movement [krəひ krəひKk] 


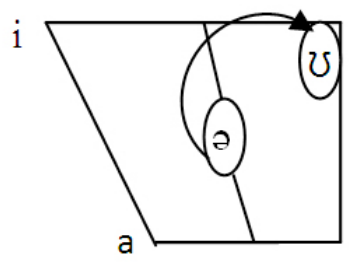

Table 5.3.1.5 Scheme of augmentativization movement [keak keak] dan [kaok kaok]

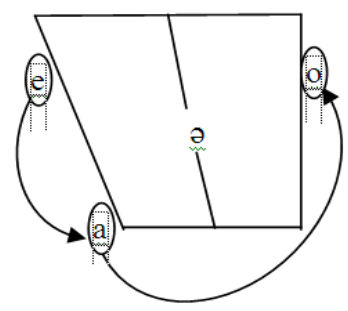

Thus, frog imitating sound in English [krəひk krəひ k] refers to frogs whose body is larger than that which sounds [rIbIt rIbIt], and crows in Indonesia also refers to birds whose body is larger than sparrows which sound [cuit cuit]/[cit cit] and definitely smaller than chickens which sound [kukuruyuk]. This is according to body magnitude within avian species.

In the meantime, the triphthong movement of cat imitating sound [miau] English, and diphthong [meon] - Indonesian can be outlined as follows.

Table 5.3.1.6. Scheme of augmentativization movement [meon] and [miau]

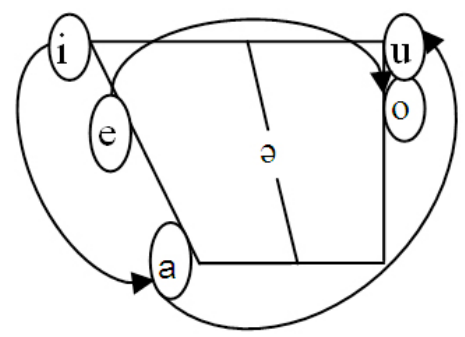

Based on the scheme above, the Indonesian diphthong [meon] moves from front to back vowel, while English triphthong [miau] moves from high to low vowel and ends up in back vowel. The end of the movement, back vowel remains to refer to a big animal, bigger than mice which sound [cit cit] and [skwik skwik], and smaller than dogs which sound [guk guk] and [wठf wరJf]. This is according to body magnitude within mammal species.

\subsubsection{Voiceless Stop Consonant ÖVoiced Stop}


When vowels are classified as front and back or high and low which means large and small, so consonants are classified as voiced and voiceless. The voiced and voiceless sounds are classified again as stop and fricative.

\section{Voiceless Stop}

Voiceless stop consonants cover phonemes $/ \mathrm{p} /$, /t/ dan / $/$. In Indonesian and English, voiceless stop evokes the impression of sound that is lightweight, fast, sudden and not gradual or does not last long. The lightweight, fast and sudden impression seems to be based on articulatory phonetics, that is how the voiceless phonemes are produced without having to involve the vibration of the vocal cords.

Table 5.3.2.1. Evidences of voiceless stop consonants that refer the sounds that is lightweight, fast, sudden and not gradual or does not last long.

\begin{tabular}{|c|c|c|}
\hline Onomatope & Indonesian & English \\
\hline Small-sized frog & [webck webck] & [rIbIt rIbIt] \\
\hline Larger-sized frog & [krok krok] & [krəひk krəひk \\
\hline Mouse & [cit cit] & [skwik skwik] \\
\hline Horse steps & $\begin{array}{c}\text { [toplak toplak toplak] } \\
\text { [kətəpak kətəpak] } \\
\text { [tuk tik tak tik tuk] }\end{array}$ & [klIpətiklıp] \\
\hline
\end{tabular}

\section{Voiced Stop}

Voiced stop consonants cover phonemes /b/, /d/ dan /g/. In Indonesian and English, voiced stop sounds evoke the sound of a heavy impression, rowdy and loud and they also connote something that collides and cruelty. The impression of heavy, loud and hard seems to be also based on articulatory factor, that is how the voiced phonemes are produced by having to involve the vibration of vocal cords.

In Magnus (2001, page 71), phoneme /b/ beginning a word in English usually refers to explosive sounds and large animals, such as bear, boar, bull, buffalo, buck. Even, the animals are small and belong to insects, they are still categorized as large and the most irritating in its phylum - bee, beetle, bug.

\subsubsection{Voiceless Fricative}

\section{Voiceless Fricative}

Voiceless fricative sounds evoke the impression of sound which is lightweight and gradual. The evidence found both in Indonesian and English animal onomatope is snakes hiss.

Table 5.3.3. Evidence of voiceless fricative consonants which evokes the impression of sound which is lightweight and gradual

\begin{tabular}{|l|l|l|}
\hline Onomatope & Indonesian & English \\
\hline
\end{tabular}


Ahmad Dahlan Journal of English Studies (ADJES), Vol 4, No 1, March 2017, 36-52

\begin{tabular}{|l|l|l|}
\hline Snake & [sss] & [hIs] \\
\hline
\end{tabular}

\section{Conclusions and Suggestion}

\subsection{Conclusions}

The research finding reveals that out of 22 (twenty-two) onomatope animal sounds gathered as the research data, there are only 15 (fifteen) sharing the same phoneme distribution after conducting sound correspondence.

The phoneme distribution occurs mostly on onset position, amounting to 10 animal onomatope sounds (chicken, cow, duck, crow, large-sized frog, little-sized frog, goad, donkey, gecko, cat). The second mostly occurred distribution is on coda position, by 7 sounds (chicken, duck, large-sized frog, snake, little bird, gecko, goose). The least occurred distribution is nucleus position, by 4 sounds (mouse, dog, little bird, goose).

The sound convergence occur not because Indonesian and English are derived from the same parent language, or for example Indonesian borrows words from English and vice versa, but it is because the nature of onomatope is imitating sounds so that unrelated languages, potentially have identical or nearly similar symbols for the same sound phenomenon. The similarities found in this study are called convergences which are caused by three factors. First, due to similarity of phoneme inventory. Second, due to similarity of phonotactics rules. Third, due to similarity of sound symbolism.

\subsection{Suggestions}

In relation to the research data, the data in this research are only about animals because they are frequently heard in daily life, often found and show up in fairy tales or picture stories. It is suggested that further research add more data on other sounds that the research findings will be much more adequate, especially when answering the issue of sound symbolism.

\section{References}

Busman, Hadumod. (2006). Routledge Dictionary of Language and Linguistics. New York: Routledge.

Chaer, Abdul. (1994). Linguistik Umum. Jakarta:Rineka Cipta.

Clark, Brian Charles. (2000). The Power of Naming: on onomatopoeia. "Essay". www.wdog.com/brian/Scriptorium/ono_naming.htm

Dagun, Save M. (2000). Kamus Besar Ilmu Pengetahuan. Jakarta: LPKN.

Dardjowidjono, Soenjono. (2009). English Phonetics and Phonology for Indonesians. Jakarta: Yayasan Obor Indonesia.

Greenberg, Joseph H. (1961). Universals of Language. USA:The M.T.T Press. 
Giegerich, Heinz J. (1992). English Phonology: An Introduction. Great Britain: Cambridge University Press.

Hinton, Leanne \& Johanna Nichols, John J. Ohala. (1994). Sound Symbolism. Cambridge: Cambridge University Press.

Kridalaksana, Harimurti. (2008). Kamus Linguistik, Edisi Keempat. Jakarta: PT Gramedia Pustaka Utama.

Magnus, Margaret. (2001). What's in a Word? Studies in Phonosemantics. Norway: University of Trondheim.

Nordquist, Richard. (October 09, 2015). Onomatopoeia (Word Sounds). [web log]. Retrieved from http://grammar.about.com/od/mo/g/onomaterms.htm

Nuckolls, Janis B. (1999). The Case for Sound Symbolism in Annual Review of Anthropology, Vol.28, p 225-252. Accessed from www.jstor.org.

Oxford Learner's Dictionary. (1991). UK:Oxford University Press.

Peters, F.E. (1967). Greek Philosophical Terms: A historical Lexicon. New York: New York University Press. 